\title{
ESTONIAN PROPHETS OF THE TWENTIETH CENTURY
}

\section{Mare Kõiva}

Leading reseracher at the Department of Folkloristics, Estonian Literary Museum e-mail:mare@folklore.ee

\begin{abstract}
Compared to famous Estonian prophets of the eighteenth and ninteteenth centuries who have left a deep mark on culture, prophets of the twentieth century have received less attention. This paper accordingly examines four prophets of the twentieth century: Aleksander Toom (Habakkuk II), Aleksei Aav (Seiu, Orthodox), Karl Reits (market place prophet, Protestant) and Priscilla Mändmets (1939-2003, global prophet, Protestant). Three of them belonged to the Brethrens congregation, while the fourth, Aleksei Aav, was Orthdox. The paper explores how upheavals in political and social life, including secularization, influenced these prophets, as well as the events in their lives that led them to become prophets. Among the main features of their activities, such as healing diseases through prayer, in our cases disseminating visions and the word of God, making doomsday predictions and predicting national or international disasters were the most important. The prophets were all literary prophets who prophesise in writing, they used to alternate between oral and written prophecy. An interesting aspect is the visions and their explanation by means of biblical passages, or the use of these passages in daily dialogues with other people.
\end{abstract}

Keywords: prophet, doomsday, Soviet time and prophets, Estonian literary prophet, vision 


\section{Introduction}

While prophets have been a part of all cultures from early history to the modern period, their role in early Estonian culture is difficult to define and remains rather speculative. There is more material and research from the period between the 17th and 19th centuries, when pietism and the Brethren movement led to the emergence of a popular church and houses of worship with an approach that differed from the mainstream, through the spread of teachings of charismatic leaders and the followers and the congregations gathering around them. The Estonian prophetic tradition spread with the awakening movement of the Brotherhood movement, which saw the Brethren enliven religious life and also brought out religious leaders as well as prophets. Recognition of prophets from among the ordinary people involved a liberal and expanded approach. They interpreted the Word of God in a unique and personal way, sharing personal visions, revelations and messages. However, what they all had in common, despite their vastly different backgrounds and aspirations, was and is their personal charisma.

As well as delivering religious messages and spreading the Word of God, prophets had a number of other important functions. The role of leader and prophet included mediating social and economic hardships and offering solutions to overcome them. The same role is also seen in the context of natural disasters, such as explaining drought, torrential rain and other extreme weather conditions, where providing spiritual comfort to one's own group was an important part of the task. The emergence of prophets in a situation of social strain is natural, and we are still witnessing the emergence of unexpected advocates, most recently in relation to the climate crisis movement. In the Estonian tradition, the development of literacy in the eighteenth and nineteenth centuries, especially with the support of the Brethren congregation, and the process of uniting of people into a cohesive community, accompanied by an increase in self-awareness and the expansion of opportunities for emotional self-expression during church services, are highly valued. Prophetic messages differed from the positions of the mainstream churches on several points: thus, we find protest messages from the prophets of the preceding centuries against the rights of the elite and the injustices suffered by the Estonians (cf. Sild 1929; Sild 1935; on East Africa, Kustenbauder 2008). In the case of Estonia, for example, the leaders of the Brethren movement, led by Zinzedorff, financed the printing of a full version of the Bible in Estonian in 1739. 
The twentieth century is a very interesting period in the culture of the small nation, characterized as it is by winning independence from and then losing it back to the Soviet Union, living in an empire with various restrictions on religious activities, and then the second restoration of independence. The fate of the prophets of the 20th twentieth century has so far attracted less attention, even though that century was characterized by turbulent events and unprecedented periods of religious persecution and social stress that led to the growth of prophetic messages.

Vernacular or folk prophecy in Estonia in the twentieth century has been directly linked to the spontaneous, ill-considered and illogical behaviour of the prophets. It has been pointed out that for their part the church members and disciples of a charismatic pastor do not control what they hear or experience rationally when being together with that individual (Bloch 2005). Today, almost every preacher talking about the future is called a prophet in everyday language, and it is customary in the media to attribute the title of prophet to prominent analysts and predictors of social and economic processes.

This study is based on a corpus of studies covering ten Estonian prophets and focuses on the activities of four of them, their written legacy and the folklore about them: Aleksander Toom (also known as Habakkuk II), Karl Reits, Aleksei Aav (also known as Seiu) and Priskilla Mändmets. The personalities selected for this study were influenced by the Brethren and Baptist movements and, in the new socio-cultural and political circumstances, continued the traditions of previous centuries, leaving behind personal letters, prophecies and biographical notes. Through the legends surrounding their personalities, they have become part of popular folkloric communication. Their lives and teachings have been revisited at moments of social or economic crisis, parallels have been sought with their predictions, and their messages have been used to interpret current events.

My main research questions are the following: (1) How did historical events influence the prophets, and what events in their lives led them to become prophets? (2) What are the main features of their activities and prophecies? (3) What beliefs are associated with their prophecies and, in turn, into which types of folklore does this associated folklore fall? (4) What are the similarities and differences between these twentieth-century prophets and earlier traditions of prophesy? 


\section{Brief overview of earlier studies}

Nonetheless prophetic lore was the focus of scholarly interest in a couple of periods, especially between 1920 and 1940. Much has been written about certain outstanding individual prophets of the seventeenth and eighteenth centuries, such as Tallima Peep (Sild 1929) and Lüütsepa Jaan or Taeva Jaan (Põldmäe 1937), who were active as prophets in the eighteenth century.

Järve Jaan, an eighteenth-century prophet represented by a number of texts in the Folklore Archives, was categorized by the folklorist Johann Matthias Eisen (1921) as the one of those influential individuals who belonged within the discourse of earlier prophets about whom peoples told stories even at the end of twentieth century. The next wave of researchers dealt with the origins, destinies and revelations of individual prophets, and their impact on their close religious groups (Põldmäe 1935, 1937; Sild 1929, 1935; Masing 1993 [1934-1935]; Salve 1998, 2000). Primarily, the relevant observations extended to the religious leaders and prophets of the awakening movement of the Brethren congregations of the eighteenth and nineteenth centuries. The more extensive prophetic movement - the so-called 'heaven-goer' movement - was practised at the beginning of the 19th nineteenth century. Among the prophets of the time there were also women and teenage girls (Põldmäe 1935; Sild 1935; Kalkun 2006). In Põldmäe's opinion, the 'heaven-goer' movement embraces abundant general human characteristics, which are apparent in every nation if the appropriate circumstances arise. The major prophets of the nineteenth century also included Maltsvet from north Estonia (Masing 1993 [1934-1935]), Kordo from the southeast of the country, Vastseliina (Salve 2000) and others.

In the late twentieth century, church publishing houses began to record the experiences of evangelists and clergymen (Kirjamägi 1997, 2004, 2006; Sirel 2012, 2013), as well as memoirs, which also provided information about the lives of the prophets (Hahn 1999). Jaanus Plaat published overiew of Estonian prophets from the eighteenth to the twentieth centuries (Plaat 1994).

This article continues my project on mediums, prophets and the magic of words. Previously, I looked at the evolution of the religiosity of the first promoter of Buddhism, Karl Tõnisson (Karlis Tennisons), popularly nicknamed Barefoot Tõnisson and known by the moniker Brother Vahindra. Based on his written legacy, I briefly characterized his religious and political quests and doomsday proclamations, his formal and informal education, his behaviour in his homeland and his fate in the Buddhist world (Kõiva 2010). Tõnisson was 
an important figure in the religious life of the twentieth century, comparable in fame to Prophet Maltsvet, a symbol of earlier religious movements. Looking at the topic of prophets from a somewhat different angle, namely the wider scope of prophetic predictions, in my studies I discussed the folk end-of-the-world premonitions (Kõiva 2007) and the written legacy of the Brethren, especially the heavenly scriptures (Kõiva 2019), as well as the example of some folk healers who were called prophets (e.g. the Witch of Äksi). All these themes are linked to the earlier charismatic movements of the seventeenth to nineteenth centuries.

\section{Aleksander Toom, Habakkuk Ii (1823-1907)}

Aleksander Toom, also known as Männiko Sander, though mainly as Habakkuk II, was the most famous prophet from Saaremaa, about whom his contemporaries and future generations of islanders have much to say. The prophet completed Valjala parish school and then trained as a weaver in Riga. From 1844 to 1850 he was a sacristan under the pastor of Anseküla, M. Körber, and was associated with the Brethren movement. Körber was renowned for his literary talent, and several of his poems were still circulating as folk songs among the islanders as late as in the second half of the twentieth century. From 1854 to 1874, Toom worked as a forest warden at Lööne Manor in Kogula village, and from 1876 he lived on Kissa farm in the village of Uduvere.

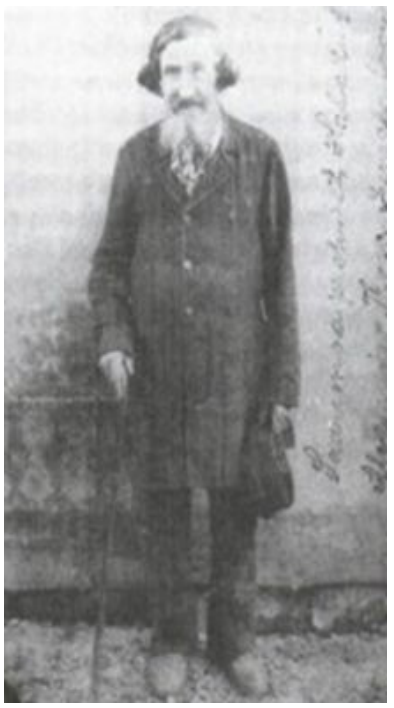

Figure 1. The prophet Habakkuk II. Private collection. 
He started prophesying in Saaremaa, in the Haage prayer house of the Brethren, near Tõnija, where he became a popular Reader. A good knowledge of the Bible and church conventions, literacy and a personal relationship with God and faith also characterized Toom, wrote local pastor Traugott Hahn in his Memories of my Life (1999: 271):

A man of barely average height, with reddish hair and a beard, which was actually more a goatee. An old grey felt hat covered his head and tangled hair, a grey homemade robe covered his body. His face was skinny, almost gaunt, his facial features sharply drawn, his grey eyes mostly flared restlessly, but he could also look at you quite kindly as he hoped people would understand his prophecies.

However, Toom was expelled from the Brethren because of angry landlords, as he severely criticized landlords and church elders in his sermons. Young pastor Hahn describes how a man who introduced himself as a prophet urged the pastor of the Pöide Lutheran Church to cooperate, which the pastor refused to do. Hahn had chosen the Pöide congregation in Saaremaa, where Lutherans had become a minority after the massive conversion to the state church of the empire, the Russian Orthodox Church, in the nineteenth century, that is, from 1860 onwards (Plaat 2001). However, there was another attraction in the parish, namely the Brethren movement, which, with its prayer room, had an important role in the community. At the same time, the region's school buildings were in a poor state of repair, so that some schools were housed in farms, while the small Lutheran congregation was unable to support their renovation.

Prophet Habakkuk II was deeply offended by the pastor's refusal to cooperate. At the same time, Hahn, who had grown up in the spirit of the classical Lutheran Church and was a follower of its customs, was surprised by what he experienced at the congregation's prayer service: unlike at a normal service, people's behaviour was very emotional, and they even shed tears.

Pastor Hahn of Valjala Church recalls:

Shortly afterwards, one Sunday morning, when I went to church, Männiku Sander was standing in the church gate preaching, gesticulating and shouting fiercely. I asked the people who were standing quietly nearby to go to church. When they followed me, he left, cursing loudly. Similar behaviour happened again soon. But even his own relatives, his wife and children, no longer wanted to listen to him. (Hahn 1999: 272) 
The young pastor's Estonian was still not yet perfect, but his innovations and kind attitude towards people meant that support for the Lutheran Church was growing. The landlord and the clergy took action against members of the Brotherhood who were more critical of social conditions, including the prophet Habakkuk.

There are several versions of how the prophet got his name. In one, during a quarrel with Valjala pastor Hahn, Toom claimed that if the pastor was Kukk (German 'Hahn'or cock), then he was Habakkuk (Hahn 1999: 272) - a linguistic joke. In Hahn's recollection, this is associated with Toom's attempt to call on him to cooperate, because

[---] all this was allegedly clearly foretold in the Bible. Prosperity was supposed to begin from Valjala. If a rooster ('kukk' in Estonian, 'Hahn' in German) is at the top of the church steeple, a Kukk is in the pulpit, and Habakkuk is outside among people, then there would be bliss. 2 Peter 1.19 makes it clear that the prophetic word is to be taken heed of 'until the day dawns and the morning star rises'. Now he, Habakkuk 2, is the star of the morning star, because he comes from the village of Koiküla (Koikla) [--]. Koiküla - the village of dawn.

A second version involves a personal vision after the expulsion, or later, when praying in a pasture.

One morning the prophet, who had not yet called himself a prophet, went to his pasture to have a look at the hay barn. There he spent time praying reverently. Suddenly God revealed Himself in the form of a fiery red disk, on which the following words were written: 'You must be called the Prophet Habakkuk 2.' So he received a task and duty from God to become a prophet called Habakkuk 2 on the island of Saaremaa. He also learned the actions and manner of speech from the ancient Israelite prophet Habakkuk. (Hahn 1999: 272)

There have been arguments for and against this version, and Toom is said to have invented the story himself. Different views highlight the attitudes of the community.

Toom describes his calling as follows:

I, upon the commandment of the Lord, and the casting and sending of God of the Holy Trinity, had to go to the doors of the church in 1871-1878 
with the Bible. For seven years I had to read and explain how evil and sinful they are; read about His death, the story gone wrong, and shout... (Kallas 2005)

We can find in his descriptions critical attitudes towards the Lutheran Church and conflicts with the clergy, based on theological differences.

Toom grew up in the spirit of the Brethren movement, but he also saw the rise of new movements that criticized the religious apathy of the Lutheran Church as well. Even after a quarrel, his mission remained to proclaim his message in the Church of the Brethren, to awaken people to the faith and to warn against a lack of faith, which would be punished. The second topic is connected with social criticismof the ways of life of the manor and church rectory, which rested upon the work of the peasants, the harsh treatment of the ordinary people and the formality of religious life.

Habakkuk II's credo is summed up in the old-style message of his epitaph:

Oh surrelik mind mäleta. Siin hingab nüüd see hüidja häel. Sõddis kurratitega Kuressaares ja saadanatega Saaremal nähtavalt 1871-1878 ja sõdis veel 1881-1900. Pangem ometi tähele mis Jumala suu on räkinud. Nenda teen veel hauast oma tööd.' 'Oh you mortal, remember me. Here rests the voice of the crier. He was at war with devils in Kuressaare and brutes in Saaremaa from 1871 to 1878 and was still fighting from 1881 to 1900. Let us take heed what the mouth of God has spoken. I continue my work from the grave.' (EFITA F01-028)

\section{The Market Place Prophet, Karl Reits (1885-1941)}

Karl Reits was popularly nicknamed 'The Doom is Nigh!' His most important prophecy is considered to be his prediction of the destruction of the Estonian state because the people had lost faith. Reits acted as a prophet during 19291941. He belonged to the congregation of the Brethren and prophesied the coming of the beast as a great calamity and as starting a time of slavery for Estonians and urged people to repent in order to be saved. A 1933 newspaper depicts him in a suit and hat, ascetic-looking with a distant yet nervous gaze, walking around Tallinn marketplace and shouting: 'Doom! Doom! Doom! Fallen is Babylon the Great!' (Päevaleht 1933). 
Karl Reits was born into a wealthy merchant family and grew up with two brothers and sisters. He was well-educated, having graduated from the Tallinn City School and while young having married a girl from Central Estonia who was ten years his senior. Their son Voldemar was the couple's only child.

Being imprisoned by the Germans during the First World War was a lifechanging period in Karl Reits' life. Over the course of seven years, he survived a series of life-threatening situations when it was uncertain whether he would survive or be shot. Although he was, for example, an overseer of other prisoners and an interpreter during his seven years in prison, his years of imprisonment left their mark on his personality and influenced his behaviour. After his return from Germany in 1921, he went to work as a turner at the Ilmarine factory, but was dismissed in 1932. From then on, his livelihood depended on donations and other precarious sources of income from believers and those who listened to his preaching.

The evangelist Andres Kirjamägi (2004: 37), who has written about Reits, points out that, in spite of his pre-military promise to devote his life to serving the faith, Reits did not immediately fulfil it, but led an ordinary life. After serious bouts of sickness, from which he was healed by prayer, he finally turned to faith only after his son's severe middle-ear infection, which was also healed by prayer. These events took place in the four years after his return home from Germany and led to a deeper understanding of the teachings of the Bible. His final crisis probably came during the illness of his 24-year-old son, who caught a cold in 1927 when visiting his fiancé and died of pulmonary tuberculosis in January 1930. Reits' wife died of cancer in 1938.

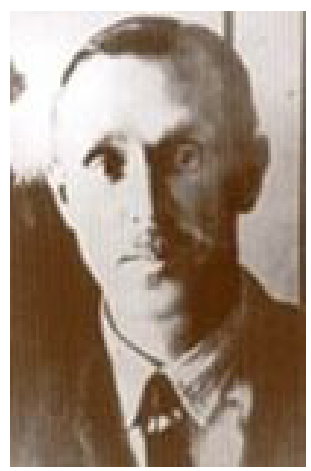

Figure 2. Karl Reits. Press photo.. 
Despite his educational advantages, Reits' life was difficult: on the one hand, it was determined by the First World War, which was prolonged by his imprisonment and took its toll on his mind and body; but also his health and job prospects were not the best when he returned home. He had a responsibility for his family but was also bound by the religious vows he had made. According to his interpretive model, personal misfortune can be overcome by prayer, which led him to an interpretation of wider events.

His major revelations began in 1929, when he was 44 years old. On the morning of 23 July 1929, at 5 a.m., he received the first divine revelation: 'When you see Jerusalem being surrounded by armies, flee to the mountains, because its desolation is near.

On 30 July 1930, he received the second revelation: a heavenly voice said to him, 'Write on the door at your work - the time of grace will soon be over!'

The third revelation came on 3 August 1931 at 8 a.m. with the words from the Book of Revelation: 'The plagues of God are coming upon the people, for the people are wicked.' Then Reits began to preach the gospel of grace, first in the churches, and after being expelled from them, in the market place. He was repeatedly punished and arrested for holding unauthorized meetings in public places and for obstructing traffic (Kirjamägi 1997).

On 16 October 1933, the newspaper Päevaleht wrote about the celestial task that had been given to Reits:

Preach to the people, for the people are evil and ungodly, that it is the end time, and the people must reconcile themselves to God in good time, before peace is taken from the earth... The sea of wickedness is full of those drowning; go to big markets and fairgrounds, people come there from every corner of the city. Speak what has been proclaimed through the prophets and what God is going to do at the end of time.

The first period included preaching in the market place and the city, where he prophesied even long years of tribulation for the Estonian people based on biblical passages. As a result, he was banned from churches and other places of worship. There were many who mocked him in the market place, calling him crazy or a false prophet. According to folklore, the prophet's tormentors would always lose their health and sanity, and a predestined calamity would befall them: 
Once a woman in the market threw a rotten cucumber at him. Reits turned to her pensively and said, 'You threw this at me as a human being, but know this, you threw it at a prophet of God!' Later, the woman met a believer in her village and told them what had happened, adding: 'My right hand is weak and withering. This is God's punishment to me for throwing a cucumber at his prophet.' (Kirjamägi 2004: 25)

Or another example:

A rich lady became irritated at the prophet's words and snarled viciously: 'Why are you talking nonsense and disturbing the peace of people?'. The prophet's answer to the angry lady was brief: 'God's punishment is not far off!'. A few days later, the same woman's dead body was lifted into a car in front of the prophet and taken away. (Kirjamägi 2004: 26)

This message, written in the 1950s, is typical of prophecy, as the author recounts several events and gives details of the fulfilment of the prophet's predictions. It is also typical to include a broader characterization of the person in question and to add one's own knowledge of his or her life and background, which are not covered in the article for lack of space.

It happened in late winter/early spring of 1939, when there were rumours that there was a man in the marketplace in Tallinn, walking among the people in the marketplace and proclaiming doom for Tallinn.

At the time when such rumours were circulating, I was in Tallinn one day in March, in the marketplace, and I saw the man who proclaimed doom for Tallinn. He was walking in long, smooth strides along the paths of the marketplace, bareheaded, holding his hat in his hand. Hair carefully combed, face sad and serious, dressed neatly and tidily. As he strode through the crowd, he shouted loudly: 'Doom is nigh, doom is nigh! Your walls will be torn down, so that not one stone will be left standing upon another! Doom is nigh, everything will come to an end!' His next words were those found in the New Testament, in the Book of Revelation to John.

Some time later, I saw this man again in the marketplace in Tallinn, and then I heard almost the same chants from him that I had heard before. 
This time he was followed by a gaggle of young boys laughing and talking to him; some even threw scraps of food and fish heads at him.

Then he stopped and said to those who were mocking him: 'The time will soon come when you won't have what you're throwing at me now - the fish and the bread will be gone.'

It was also said that the man had been told by the police not to have such conversations in the marketplace, but then he responded to the police by saying: 'You can ban me, but my words will still stand, while you will die!'

And on the evening of the 9th of March 1944, a large number of planes (a squadron) with flares appeared over Tallinn and dropped firebombs and destructive missiles on Tallinn. Houses were set on fire and buildings collapsed, and many people lost their lives. Many were left homeless, and many suffered from wounds and had to continue living as cripples.

And so the prophecies, which had been ignored when he proclaimed them in the Tallinn marketplace, were fulfilled. [--] (RKM II 110, 401/6 Tallinn, 1961)

\section{Power and the prophet (Reits)}

All the popular prophets in earlier centuries had encounters with public officials, the police and the judiciary, who were not comfortable with their existence. As a rule, any attempts by the authorities down the ages to stop such prophecies have merely had an encouraging effect on both the prophet and especially on his disciples (Põldmäe 1935; Kõiva 2007). Reits was constantly at odds with the leaders of the church and was chased away from all major churches and houses of worship in Tallinn. The posters containing the word of God that he hung on church doors were immediately taken down, to which the prophet responded with a prophecy that the preachers and the pastors themselves would be put on trial (RKM II 110, 401/6 Tallinn, 1961).

There are also stories of Reits receiving advice from those in power: 
[--] Seeing his courage, the authorities later became more lenient towards the prophet. One of them approached the prophet and said kindly: If you want to proclaim your message to the people in a public place, don't stand, but walk slowly and speak. Then there will be no gatherings and the authorities will have no reason to harass you.' The prophet began to follow this advice. (RKM I 23, 262/8 (6) Vastseliina, 1990)

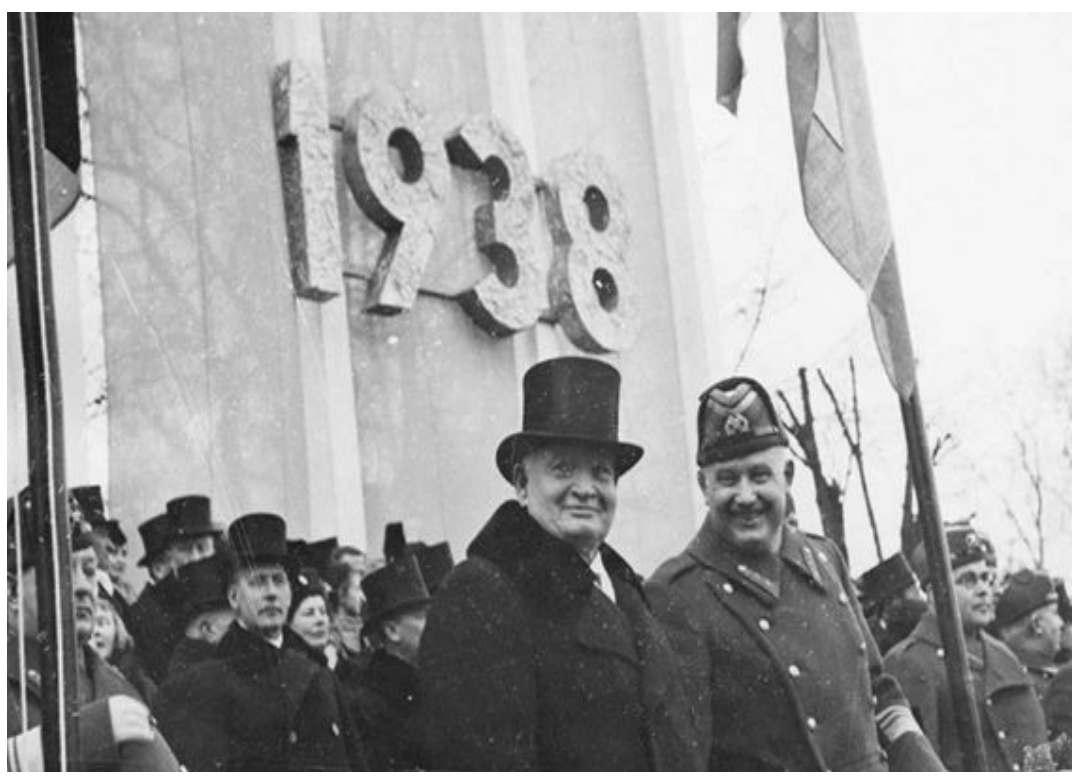

Figure 3. President Konstantin Päts and General Johannes Laidoner in 1938. Private collection,. 
At the same time, the police had even responded to his annoying predictions by saying, 'Such people should be wiped off the face of the earth!'. It should be remembered that the ideas of eugenics began to spread in both Estonia and Europe generally in the nineteenth and twentieth centuries. While in Estonia the attention of both doctors and politicians was focused on the question of how to increase the number of children and on the temperance movement, the idea of forced sterilisation was also on the agenda (see Sõnumed 1933; Kalling 1998, 2007). Dissidents were not favoured in the silent era of the 1930s, and many memoirs have documented frequent arrests.

Kirjamägi (1997:18; also Sirel 2012: 64) reports the following:

While in prison, I [Reits] was accepted by secular people and unenlightened pagans. They sympathized with me and said: 'We are the guilty ones, and we have to go to prison, but you have no guilt! Preaching God's Word is allowed, after all!' Such persecution is easier to endure than persecution by believers who are spiritually blinded.

Besides the clergy, the police and the prisons, Reits had frequent encounters with members of the government. It is known that General Laidoner (served as an Estonian general and statesman, was Commander in Chief of the Estonian Armed Forces during the Estonian War of Independence, and was counted as one of the most influential people in Estonian history between the world wars, died in GULAG 1953) had him repeatedly arrested and even beaten with a truncheon (Sirel 2012: 58).

There are even more folklore records of meetings with President Konstantin Päts (1874-1956), the head of government in the silent era of the 1930s. It is known that Reits met Päts approximately three times and that the President promised him a pension for life if he stopped parading around and intimidating people. To this the man of God allegedly replied: 'It is not in your power to promise me this, for your own pension is not certain either!'

Another popular story is about how Päts had an expensive crypt built for himself in the Forest Cemetery near his farm, about which Reits prophesied: 'You can build this crypt, but your bones won't be buried in it!' Päts listened politely to the prophet's speech, then put his hand on the man's shoulder and said condescendingly: 'Listen, man, you have gone mad with hunger. Go to the kitchen, the women will feed you. 'Understandably, the stories about both leaders have attracted a lot of popular attention, as President Päts died on 18 
January 1956 in a mental hospital in the city of Kalinin in Russia, and General Laidoner perished in a Siberian prison camp.

A major concern was the diminishing importance of religion in society, as reflected in Reits' notes and preaching. The same concern is also at the heart of the opinions of other prophets, as well as of ordinary people. In 1941, on one of his evangelical journeys, Reits encountered a Latvian death squad near his wife's birthplace and began preaching to them. It is thought that he may have been shot because he did not speak Russian and could not understand the orders they gave him. He is buried in the cemetery on Otti Farm. The following letter was found in his pocket:

I want to inform you of everything that Jehovah God has told me about the Estonian state. This beautiful republic, which God has given to the people of Estonia, will be taken away from them because the leaders and the people have forgotten their God. And it will be given away. The head of state gives the state up voluntarily. For what wisdom has the leader who doesn't know God?

A great fright will come upon the leaders: they will be imprisoned and taken away, and the people will fall under the yoke, where they will suffer from hunger and thirst and anguish. The fire suddenly descends on its wings over the cities, and no one has peace. And the cities of many lands shall be destroyed, and many nations shall be afflicted. The Estonian people will be dispersed until the nation has perished. And I heard a loud voice on the right side of heaven shouting, 'Ask the Lord Jehovah, who made the heavens and the earth and the fountains of waters!' (Kirjamägi 1997: 40)

This is undoubtedly one of the most poignant texts of a prophecy to describe the calamities of the near future, and as such a very influential text that was later repeatedly referenced.

\section{Aleksei Aav, Prophet Seiu from Saaremaa (1909-1996)}

Seiu was born on Matsi farm, in the village of Metsara, Saaremaa, but from the first year of his life he lived with his foster parents, Ekaterina and Daniel Aav, on Allaniidi farm, in the village of Reina. His foster parents raised him from the age of one. Seiu's parents had seven children, and according to the custom, 
relatives helped to raise children if necessary. Seiu himself also had a large family, a total of nine children, some of whom had interesting Estonian-style first names, in keeping with the fashion of the time (Tõeleid 'Truth', Õnnepäev 'Happy Day', Õiguleid 'Righteous' - GENI.com).

He was one of the most interesting and versatile prophets of recent times, many of whose writings have survived, including correspondence, but this is still largely unexplored. In the 1980s, Seiu's manuscripts were collected by Juhan Saar, a local bibliophile from Eikla, and it is thanks to Saar that they have been preserved. The manuscripts were among the attractions that the bibliophile loved to show to his book-loving guests. Although the prophet lived a long life, much of which was spent in the family circle, that rural family had no interest in literary culture.

Seiu was a successful breeder, grafting compatible varieties and breeding apples, pears and other species. Many of the species he created are still grown today (e.g. the pear called Seiu). The variety's pedigree information describes it as suitable for home gardens, with fruit ripening gradually, keeping for a few days and being juicy (SESTO). Seiu was well known in the neighbourhood for his fruit trees and also for his peculiar behaviour. A local resident recalls:

The people of Pöide municipality remember the use of the loudspeaker
in their Facebook group. Evi Klooster used to work in Tumala Library
at that time and was asked to count apple trees in the gardens of Reina
village. 'There were a lot of them at Seiu's place,' Evi Klooster recalls. 'I
also remember him singing through his megaphone in a tree at the gate
of Pöide Cemetery'. (EFITA F01-028)

In 2004, locals recalled that he was kind enough to give children a ride in his horse cart: 'He was my grandpa's brother. We often got a ride in his horse cart when we came home from school.' (EFITA F01-028)

\section{Power and the prophet (Seiu)}

Seiu became more widely known by sending memos to both Hitler and Stalin, saying it was necessary to enter the Millennial Kingdom of Peace. During the Soviet era, he preached wherever the people gathered, e.g. standing on a wall or even climbing a tree on Cemetery Day. This is another remarkable quality that he was remembered for in the stories that spread in the village. 'We must 
be hot, not lukewarm, in our faith. And make the world a great kingdom, a country of Christ, where people do not even learn to fight', Seiu wrote in one of his booklets. 'Even on his deathbed, Seiu did not think about worldly things, but pleaded: "Do, my children, everything to reconcile Palestine and Jerusalem," says Rutt Kivipõld about her father Seiu, the prophet of Saaremaa. 'His main concern was that the Millennial Kingdom of Peace should be established and that Estonians should start working for it to happen' (EFITA F01-028).

Seiu had mysteriously been given visionary or prophetic messages, which he himself calls the prophecies of the Spirit of Truth. As he recounts, these prophecies were revealed to him on the night of 6 October 1938 between 2 and 4 a.m. in his semi-awake state by a spirit in the form of an unknown man of medium build, clean-shaven, in a grey outfit, middle-aged or younger, very kind and polite, with a strong desire to make these prophecies known to all nations.

Exactly one month later, on the night of 6 November 1938 between 2 and 4 a.m, he had the same vision. Seiu was therefore a little anxious and wrote the prophecies down on paper, but delayed making them public, wishing to wait for things to proceed. On the night of 6 December 1938 between 2 and 4 a.m., he had exactly the same vision for the third time. Now Seiu could no longer resist the urgent desire of the man in grey clothes. It had become an inner urge for him to make the following prophecies public:

\section{1) About the Estonian state, the Spirit of Truth says:}

A small young man among his brothers, who is considered poor and insignificant and despised by all, will save Estonia and pull her out of the swamp into which Estonia and her sisters have been dragged, and will take her out of the claws of black vultures into the large house of her parents, into the upper room, where Estonia and her saviour will become engaged as a solemn bride and groom. (EFITA F01-028)

\section{2) About the German Third Reich, the Spirit of Truth says:}

Behold, with the palm of my hand I will beat down the two and a halffeet of the man that is painting with blood, and from head to toe, has stained his garments with the blood of my saints and the righteous of my Father, which has dried and turned brown. You shameless beast, who is watching on the hill and bargaining like a white-robed Jew frrom the south, to get 
their 'oxen' for very little money. Behold, I will squeeze thee with my right hand, so that thy bones will crack, and I will set thee on your back before the men of the north, and lay upon you three crosses to be a burden. But this stubborn seed will still get up to sit, and then I crush him for good and lay upon him three other crosses. And so, I put him under the burden of six crosses for twenty hours, leaving him under the control of these greyrobed men of the north. (EFITA F01-028)

3) About general truths, the Spirit of Truth says:

I want to disturb the enemies and jumble all the enemies of the enemies together and mix them well. The nations must see how I have done everything in the right way, so that you must believe and respect the One who is doing everything. And you, human beings! Why do you rush back and forth like crazy from one place to another and search but can't find what you're looking for?! Stop for a moment and search through my Ark of the Covenant, plated with pure gold, inside and out, thoroughly and freely, and very decently. For that, I have put in place everything you are looking for. And I will be able to lift the lid, so that you may correctly see and recognize everything you have been looking for. (EFITA F01-028)

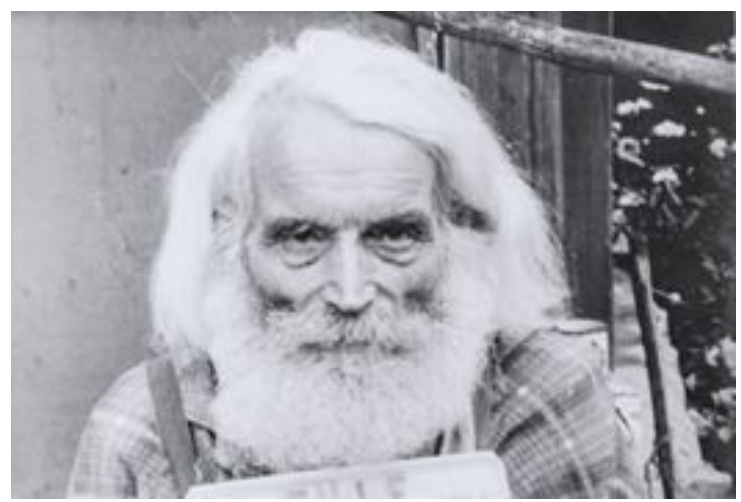

Figure 4. Prophet Seiu was a successful breeder. Private collection.. 
As Seiu explains, further explanations of the last prophecy were promised so that it be understood correctly.

If we were to highlight one of the guiding ideas of his prophecies, it would be the dream of a world without wars. Given that his life was marked by the First World War, the War of Independence and the Second World War and their consequences, this dream seems perfectly logical.

\section{Priskilla Mändmets: God's Envoy on Earth (1939-2003)}

Priskilla Mändmets was born on 7 February 1939 in Tallinn. She studied at the University of Tartu and the Modesto Bible Institute, majoring in history and journalism, and she called herself a missionary evangelist.

'The Jewish conspiracy' was probably what Priskilla feared most, because she touched on that topic whenever possible. She spoke about it on 29 August 2001, at a rally against the sale of the Narva power plants in Toompea. She considered her mission quite important. She even founded the Union of Prophets. The question is - when have prophets been right in the head, and when have they been able to behave in a socially correct way?

Mändmets' activities were widely covered in the press, and as a logical follow-up to this attention, Jaan Kolberg made a documentary film about her in 2004. This eccentric lady ran for a large number of different high positions, seized every opportunity to appear in the media and delivered apocalyptic prophecies to the Estonian people. A schoolteacher and local correspondent, Kaleph Jõulu, wrote about his encounters with Priskilla. Jõulu recalls:

It was in late September 1992. I was in Haapsalu, in the neurology and orthopaedics hospital at Suur-Mere 30, receiving remedial treatment. One day I had a visitor, a short, brown-eyed middle-aged lady who, with her sporty travelling outfit, gave the impression that she was into hiking. Her looks didn't show that she was already 53, because she was bursting with energy and in perfect health. She immediately told me that she had got my contact details from a friend of mine (a young disabled man from Paide) whom she had met by chance in Haapsalu. Priskilla Mändmets, that was the name of this nice lady, remembered me from the time I was the principal at Roosna-Alliku school (Paide district) (1962-1965); she was a teacher in Väätsa and became the director of studies at Roosna-Alliku school after I had left. Priskilla was educated in Haapsalu and graduated 
from Tartu Pedagogical School. In 1969, she graduated from the Faculty of History at the University of Tartu, and in 1991 from the Faculty of Journalism. She had been an educator for 32 years. She now made a living by selling handicrafts and preached God's truth to the people. Priskilla told me that she was born in Tallinn as the eldest daughter of a missionary father (a Pentecostal) and an evangelist mother. Her name comes from the Bible: the biblical Priscilla was one of the founders of the early Christian church. Her father saw in his six-week-old daughter his successor. She was consecrated in this faith on the day the Molotov-Ribbentrop Pact was signed. 'Nothing happens by chance in this world; we are led by the Spirit of God,' insisted Priskilla.

At the hospital, she would distribute religious scriptures to patients and invite those who were mobile to prayer meetings. A young fellow from my ward went to one meeting and told me about the experiences they offered. I was not interested. Recently, Priskilla as an Envoy of God had started to receive more press coverage. (RKM I 30, 233/4 Viljandi (1992)

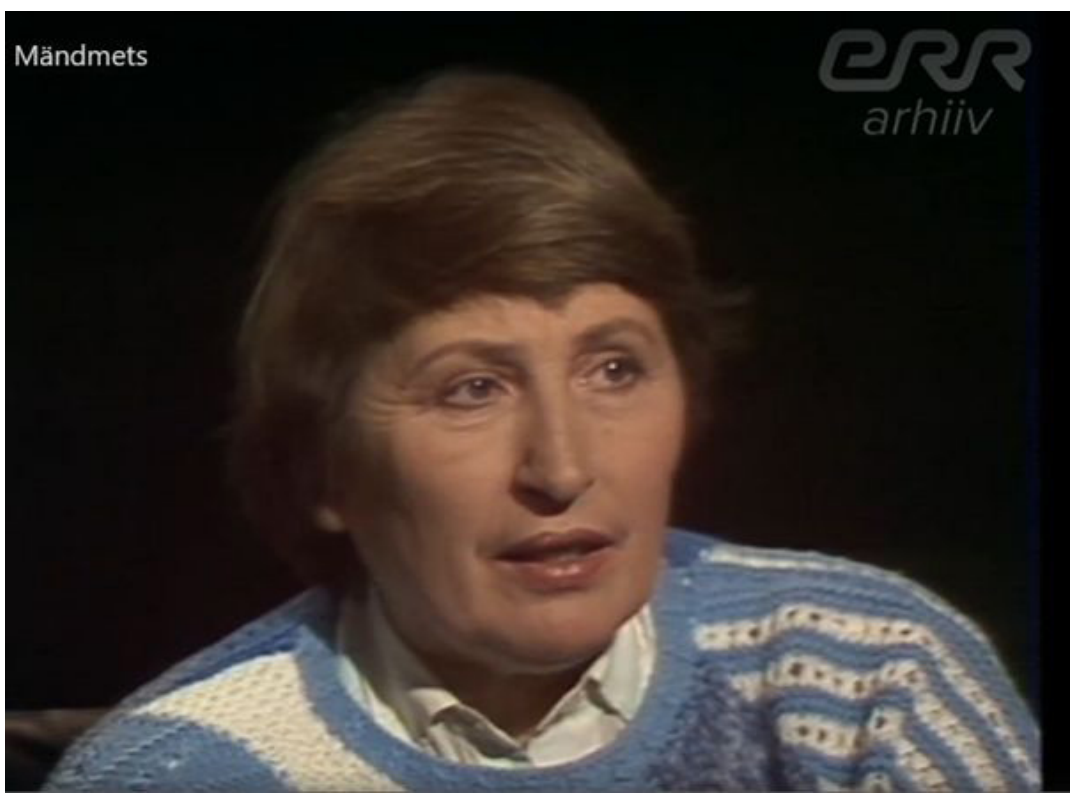

Figure 5. Proskilla Mändmets in TV show. Screenshot. 
Priskilla's letters reveal her ongoing missionary work among members of the government and the leaders of political parties, as well as communications with many people whom she happened to meet. Here are some examples from her letters of 1992:

I need to go to Ülo Vooglaid (he's in the Parliament, I am on first name terms with 16 members of the Parliament) and establish a faction of saved Christians' and God will work through that faction. Lauristin (needs to be saved), Raave, Alli Toomik - my 1st benchmate, a doctor from N-Jõesuu, a distance student of journalism... (RKM I 30, 235/6 Viljandi, 1992)

The next example describes missionary work among members of the government and military people:

On the 24th I was in Tallinn and I caught seven big fish: Aino Barbo, Kajane Kurbanova [?], Indrek Toome, Kalle Kulbok, Colonel Laaneots, Aare Uind (Pärnu Defence League) and Rein Põder (military commander). This one got the most decent strike from the Holy Spirit, he was so distant at the beginning, afterwards it was difficult to get rid of him. Hallelujah. (RKM I 30, 237 Viljandi, 1992)

On her programmatic doctrines, she said:

I need assistants and support. I am about to go to Juhan Sepp to publish Listen to the voice of your heart in Õhtuleht. Children at school need to listen more to 'The Heartbeat' by the Sõnajalgs [the Sõnajalgs are Adventists, twin brothers who married twin sisters, musicians, later businessmen. $M K]$. Every decision and every step is so important here, leading either to God or away from Him.' ER is going to sing this song.

At the same time, her campaign also focuse on simpler issues, such as a peculiar assessments of folk customs and a view of Christmas. In this assessment, her personal opinion - 'I like it' - clashes with her Christian views. The New Year goats, an ancient New Year's Eve tradition, mainly prevalent in western Estonia and Saaremaa, is associated with charity and is supported by the Word of God:

While Christmas is made up by the people, I don't resent them for it. They are people, after all, spirits in the flesh, and they may have a few little 'things of their own', and I like Christmas as a holiday. There is peace and joy and 
great food and lots of beautiful and strange things that are not present in other times. I don't resent anything about Christmas. Not even the New Year's goats. Let them come and knock on the door! They are knocking on people's conscience, reminding them that they need to share their wealth with others, that there is no point in hoarding wealth on earth, that the real wealth is in heaven and that one must start gathering it on earth. (RKM I 30, 238 Viljandi, 1992)

Priskilla also visited museums, but her main aim was still to spread her message. Those who met her on rare occasions remember her as an interesting personality:

Priskilla was very direct, simple and straightforward. I do not remember much about her, only her dark complexion, golden eyes and short black hair. She herself approached me. For some reason, she mentioned Eenok Haamer. That she knew the man very well. [Eenok Haamer, clergyman, member of a Pietist-leaning family, head of the Institute of Theology. MK] (EFITA F01-028)

Overall impression: unforgettable, slightly crazy, but enchanting nevertheless. Um, and very open: in retrospect, it seems that she was trying to get information from everything around her. I guess she approached me at that far-off moment, because autumn and young me - we formed an idyllic sight, and it impressed her. (EFITA F01-028)

The second example describes a young person's chance encounter with Priskilla.

What is noteworthy is the lack of biblical quotations and her written visionary legacy. It is possible that more of her letters and other writings have been preserved in Estonia, and that in the future it will be possible to discover more about her personality.

\section{Similarities and differences compared to previous traditions}

There are reasons and opportunities for prophesizing in all eras, but especially so in the difficult circumstances of the twentieith century, when religious behaviour was changing. During the long Soviet period, every clairvoyant, fortune-teller or psychic who had anything to say about the future of Estonia 
was called a prophet. Some of these sayings quickly spread in oral folklore (e.g. the saying attributed to the witch of Äksi that the borders of Russia will be seen from the Kremlin window; Kõiva 2014: 177). There were also prophecies like the prediction that Estonia will be destroyed, that only Sweden will survive and that believers should therefore flee to Sweden), which remained short-lived popular beliefs, street rants and speeches, provoked by political uncertainty and destroyed by common sense.

It is also evident from the biographies of the twentieth-century evangelists and the material collected about them that people interpreted every curse, every saying, every response to improper behaviour as a prophetic message, even though it did not have the characteristics of this genre in folklore's inventory of genres. Rather, it is a situational statement, interpreted primarily in the context of the 'evil eye' phenomenon.

In the second half of the nineteenth century, alongside the Lutheran Church, the Brethren Church and the Orthodox Church (there being a more massive conversion from Protestantism to Orthodoxy in the early 1840s due to severe weather conditions and diseases), several revivalist movements spread to Saaremaa and Läänemaa (Plaat 2001) and from there further north and south. The year 1873 saw the rise of the Free Church movement among the Swedish-speaking population of Läänemaa, initiated by schoolteachers Thure Emanuel Thoren and Lars Johan Österblom. The Estonian congregations of the Free Church started to emerge during the revival movement of 1879-1882. This religious movement of free people did not recognize christening in church; listening to the sermons of clergymen who were considered sinners was seen as harmful; and the right to preach was reserved to all the brethren who spoke out of their own inspiration. The Free Church movement was not officially allowed in the Russian Empire. Other branches of the Protestant church emerged in roughly the same period. For example, the first Baptists were baptised near Haapsalu in 1884; the Seventh-day Adventist movement spread in the late nineteenth century, while in the early twentieth century Methodism took off in 1908 and Pentecostalism in 1909. At the end of the nineteenth century and the first half of the twentieth, the Baptist church was one of the fastest growing religious movements in Estonia; and since the movement had the official support of the landlords, the persecuted free-believers tried to save themselves by joining Baptist churches. For the record, the Baptist Church, like the original Brethren movement, arrived via the Baltic German nobility and was therefore 
more popular than the Free Church movement. In 1945, the Free Church was forced to merge with the Baptists for good.

In the Brethren church, the preacher was expected to have a good knowledge of the Bible and church customs, while in the Free Church the believer's personal vision was all that was needed. The 'Heaven-Goers' (a religious movement in nineteenth-century Läänemaa) also expected people to have visions and to explain them to others. While the late nineteenth and first half of the twentieth century were religiously diverse, with new doctrines and religious movements, esoteric teachings and health movements being introduced from the West, and also from the East, an ethnic religion, paganism, or Taarausk (Taaraism), as well as Maausk, which translates as 'Earth Religion', started to form in the Baltic region. The latter became one of the most influential trends in the final decades of the twentieth century, during the decline of the socialist period (Põldmäe 2011, Plaat 2003). Although not may people joined the movement, more than $50 \%$ supported it (Census 2011), and we can speculate that the reason for this was that the movement was seen as ecological, protectionist, etc. These new faiths did not add any prophets, but in the 1950s members of the Brethren, Pentecostals, Jehovah's Witnesses and evangelists with a prophetic vocation started to return from prison camps and deportation.

Stanislav Sirel, for example, summarizes in his book the lives and writings of female evangelists, missionaries and prophets in the twentieth century. This shows how important the unexpected healing that came through prayer was for many, in gratitude for which they went on missionary work to Africa or Asia. One of the female prophets, Viiu Junmann (1883-1969) from Hiiumaa, describes her spontaneous journey to Saaremaa, where she set out to heal with prayer:

[--] Earlier, I visited her mother, who was poorly. I got down on my knees, and we spoke to Jesus about the woman's plight. The woman was healed at the same moment, praising and worshipping God. From there we went together to Aleksander. He was in his forties or fifties. He lay in his bed, rolling about in great pain. He had been to Tartu, where one of his kidneys had been removed, but the pain still persisted. We prayed together from the bottom of our hearts for this unfortunate man. At the same moment, the Holy Spirit fell on the sick man, and he jumped out of bed, straight and healthy and very happy, praising Jesus Christ. (Sirel 2013:54) 
It should be noted that, as with many of the prophets described above, it was common for female evangelists to prophesy small curses and misfortunes in response to adverse circumstances.

\section{Conclusion}

The emergence of prophets and their activities are in no way limited to external socio-political, economic or identity issues. They relate to religious changes or the need for them; they originate from or are influenced by the behaviour and messages of the prophets themselves.

1) Looking at the traditions related to the ten prophets, it can be said that the events that have had the greatest impact are those related to upheavals in political and social life: major wars, outbreaks of disease (World Wars I and II), the collapse of the Russian Empire and Estonian independence, that is, situations in which power structures changed, the community was being subjected to anti-religious measures and the prophets believed that society was moving away from the word of God and the kingdom of God. Criticism of the authorities and the clergy led not only to arrests (this also happened in the eighteenth and nineteenth centuries), but also to expulsions from the house of worship and the congregation. This extreme behaviour was directed against the official Protestant church, which the prophets considered to be detached from faith: it included hanging posters on the church door, preaching in a tree, preaching through megaphone during church events, disturbing the sermon by preaching at the same time, preaching in public places outside the church premises. At the same time, prophets also took a stand against their own congregations. The prophets of the twentieth century did not build their own congregations, but instead acted alone. Since none of them achieved the position of a charismatic leader, they either travelled because of their mission or moved within a certain area (Tallinn and market places, also rural areas - Reits, various institutions, towns, offices, the parliament - Priskilla, nearby villages, vicarage - Seiu, his own house of worship and the area around the church - Habakkuk II).

One of the triggers for these activities was the religious diversity of the twentieth century; however, like the prophets before them, these prophets preached about the arrival of Doomsday because people were becoming increasingly irreligious. While in previous centuries it was the upper classes that were predicted to be doomed, now there was growing concern for the Estonians or the state. 
As with earlier prophets (also, for example, shamans and folk healers), the prophetic vocation is accepted after repeated ordeals (Bulgakova 1995, Sirel 2012, Kirjamägi 1997, EFITA F01-028).

2) The main features of the prophets' activity are the healing of diseases through prayer, in our cases spreading visions and the word of God, doomsday predictions, and predicting national or international disasters.

There are no predictions on the organization of future society or technological innovations. There are also no special requirements for their clothing: they themselves appear in the normal clothing of the era, using the technical means of their time. There are no particular requirements for leading an ascetic lifestyle, nor for clothing or jewellery, although there is a somewhat disapproving attitude towards profligacy and showing off. There are no associations with unusual atmospheric phenomena and no interpretations of cosmic phenomena as the sign of Doomsday.

3) These are prophets who prophesize in writing, in a similar tradition to the prophets of the eighteenth and nineteenth centuries. For the most part, they used to alternate between oral and written prophecy. Conversely the prophets of the twentieth century, especially those in urban settings, preferred, because of the briefness of the contact, to share individual experiences, focusing on belief, curses, prophecy, and descriptions of the prophet and of his or her appearance. Thus, for the most part, the stories are recollections and relate personal experiences in shorter one-episode narratives

One interesting aspect is the visions and their explanation by means of biblical passages, or the use of these passages in daily dialogues with other people, closer analysis of which is a future research topic. As their prophecies and social predictions were primarily about matters of faith and the kingdom of God, and as their activities took place either in the private sphere or around churches, they did not experience significant problems, for example, during the Soviet era.

In conclusion, there are similarities, but there is also a narrowing of tradition, a multitude of non-narrative plots. 


\section{Acknoledgements}

This article was written within the framework of the research project 'Narrative and belief aspects of folklore studies' (EKM 8-2/20/3), and was supported by the European Union through the European Regional Development Foundation (the Centre of Excellence in Estonian Studies, CEES, TK 145).

\section{Sources}

Manuscript collection of the Estonian Folklore Archives: H, Kase - Jakob Hurt's folklore collection, 1860-1906. RKM - folklore collection of the Department of Folkloristics, Estonian Fr. R. Kreutzwald (State) Museum of Literature of the Academy of Sciences, 1945-1996.

EFITA - Scientific archives of the Department of Folkloristics, Estonian Literary Museum, collection Prophets

\section{References}

Bloch, Maurice 2005. Essays on Cultural Transmission. London School of Economics Monographs on Social Anthropology 75. Oxford and New York: Berg.

Bulgakova, Tatyana 1995. The Creation of New Spirits in Nanay Shamanism. In: M. Kõiva and K. Vassiljeva (eds.) Folk Belief Today, Tartu: Folk Belief Studies Department, pp. 37-43.

CENSUS 2011. Population and Housing Census (PHC 2011)CENSUS 20112011 Estonia Census. Stat.ee. 1.12. 2011.

Eisen, Matthias Johann 1921. Eesti prohwet Järwe-Jaan. [Estonian prophet Järwe-Jaan.] 2nd revised edition. Tallinn: A. Keisermann.

Hahn, Traugott 1999. Mälestused minu elust [Memories of my life]. In Pesti, Olav (ed.) Saaremaa muuseum. Kaheaastaraamat, 1997-1998. Kuressaare: Greif, pp. 247-290.

Kalkun, Andreas 2006. Mart Saali ja Lüütsepa Jaani taevaskäigud: Protestantlikest ilmutustest, nende poeesiast ja motiivistikust. [Mart Saal's and Lüütsepa Jaan's Visits to Heaven. Revelations in Protestantism: Motives and Poetics]. Keel ja Kirjandus, Vol. 10, pp. 797-815.

Kallas, Ene 2005. Aleksander Toom: Jumala loom, Saaremaa suurim prohvet Habakuk II [Aleksander Toom: the animal of God, the greatest prophet of Saaremaa Habakkuk II]. Saarte Hääl, 5.07. 2008. 
Kalling, Ken 1998. Tõutervishoiust ja sundsteriliseerimisest Eestis [Breed health care and compulsory sterilization in Estonia]. Kleio 2: 27-31.

Kalling, Ken 2007. Karskustöö sünnitab eugeenikaliikumise [Abstinence gives birth to the eugenic movement]. Mäetagused 36: 60-78. doi:10.7592/MT2007.36.kalling

Kirjamägi, Andres 1997. Prohvetlusest ja selle esindajatest Eestis [About prophecy and its representatives in Estonia]. Rakvere: Rahvere Nelipüha Kogudus.

Kirjamägi, Andres 2004. Prohvet Karl Reits ja Eesti saatus [The Prophet Karl Reits and the Fate of Estonia]. Rakvere: Rakvere Nelipüha Kogudus.

Kirjamägi, Andres 2006. Johannes Matvei-Kaarep: Eesti suurim kirjaprohvet [Johannes Matvei-Kaarep: Estonia’s greatest literary prophet]. Rakvere: Rakvere Nelipüha Kogudus.

Kõiva, Mare 2007. Komeedid eesti rahvausundis [Comets in Estonian Folk Belief]. In: M. Kõiva (ed.) Sator 6. Tartu: EKM Teaduskirjastus, pp. 161-197. http://www. folklore.ee/rl/pubte/ee/sator/ sator6/, last accessed on 2 Apr 2010.

Kõiva, Mare 2010. The Last Minutes of Our Earth, Folklore: EJF 44: 131-156.

Kõiva, Mare 2014. The Witch of Äksi: Clairvoyant Person and Soviet Time. In Mare Kõiva, Through The Ages II. Time, Space, and Eternity. Tartu, ELM Scholarly Press, pp. 159-182.

Kõiva, Mare 2019. Eesti loitsud I. Arstimissõnad I. [Estonian Incantations I. Healing Words I].Tartu: EKM Teaduskirjastus.

Kõiva, Mare 2020. Molitva i zagovor: Bibleiskie motivy i kharatery v zagovorakh [Prayer and incantation. Bible motifs and characters in spells]. In: Volodina, T. and Kõiva, M. (eds.) Fol'klor i fol'kloristika: Vzgljad iz Belarusi i Estonii [Folklore and folkloristics. View from Belarus and Estonia]. Minsk: Belarusskaja navuka, pp. 12-48. Missia vypolnima; 2).

Kustenbauder, Matthew 2008. Prophetic movements: Eastern Africa. In: Middleton, J. and Miller, S.(eds.). New Encyclopedia of Africa 4, pp. 261-270. Detroit: Thomson/Gale. https://core.ac.uk/download/pdf/28938068.pdf

Masing, Uku 1993 [1934-1935]. Prohvet Maltsvet. In: Vaatlusi maailmale teoloogi seisukohalt. [Prophet Maltsvet. Observations of the World from a Theologist's Point of View]. Tartu: Ilmamaa, pp. 11-157. [Original: Usuteadusline Ajakiri 1934,156 Vol. 4, pp. 122-126; 1935; Vol. 1, pp. 24-29; Vol. 2, pp. 49-52; 1936, Vol. 3, pp. 93-103; Vol. 4, pp. 124-136; 1937, Vol. 3/4, pp. 100-114.]

Plaat, Jaanus 1994. Eesti prohvetid ja prohvetlus 18.-20. sajandil [Estonian Prophets and Prophecy 18-20th century]. Looming 9-10: 1246-1254; 1384-1402.

Plaat, Jaanus 2001. Religious Movements and Congregations in West Estonia from the Mid-18th to the Beginning of the 20th Century: Their Influence on the Estonian and Estonian-Swedish Popular Culture. Acta Ethnographica Hungarica, 46 (1-2): 161-174. 
Plaat, Jaanus 2003. Religious change in Estonia and the Baltic states during the Soviet period in comparative perspective. Journal of Baltic Studies, 34 (1): 52-73

Põldmäe, Rudolf 1935. Taevakäijad. [Heaven-goers.] Kaleviste mailt. Õpetatud Eesti Seltsi kirjad 3. [Letters of the Learned Estonian Society 3.] Tartu: Õpetatud Eesti Selts, pp. 123-176.

Põldmäe, Rudolf 1937. Se velle Lütseppa Jani ello käük siin ma pääl ehk sääl taivan. [The Life History of Brother Lütseppa Jani here on the Earth and in the Heaven]. Eesti Kirjandus, Vol. 12, pp. 611-618.

Põldmäe, Rudolf 2011. Vennastekoguduse kirjandus [Brethren's Literacy]. Tartu: Ilmamaa.

Salve, Kristi 1998. Kordo - nõid ja/või prohvet. [Kordo: Prophet or Witch]. Mäetagused 8: 58-79. http://www.folklore.ee/tagused/nr8/kordo.htm

Salve, Kristi 2000. Oh, kes saab lihakeelega üles rääkida taevased asjad! Mart Saali ilmutus. [O, Who Could Speak of Heavenly Matters in the Earthly Language? The Apparition of Mart Saal]. Mäetagused 14: 83-96. http:// www.folklore.ee/ tagused/nr14/ilmutus.htm

SESTO. Nordic Genetic Resource Center, NordGen

Sild, Olaf 1929. Tallima Paap. Usuteadusline Ajakiri, 3-4: 97-129.

Sild, Olaf 1935. Üksikasju taevakäijate liikumisest mõningate säilinud kohtuaktide valguses. [Some details of the religious movement of heaven-goers, in the light of preserved court documents]. Usuteadusline Ajakiri, 4: 109-120.

Sirel, Stanislav 2012 [1997]. Turu prohvet [The prophet of the market]. Rakvere: Rakvere Nelipüha Kogudus.

Sirel, Stanislav 2013. Eesti pühad naised. 20.sajandi misjonäid, prohvetid ja evangelistid [Estonian holy women: 20th-century missionaries, prophets and evangelists]. Tallinn: Rakvere Nelipüha kogudus.

Sõnumed 1933. Hitleri soovitused peigmehele: Kes wõib olla sakslase naiseks [Hitler’s recommendations to the groom: Who can be a German woman]. Sõnumed nr. 179, 19.08. 1933.

Mare Kõiva is Head of the Centre of Excellence in Estonian Studies, and Leading Research Fellow, Head of the Department of Folkloristics at the Estonian Literary Museum, Estonia, member of the Academiae Europeana. Her main area of the field reasearch is Estonia, Bulgaria, Belorusia. Her research areas are charms and charmers, belief narratives, mythology, and human/non-human relationships. 